\title{
THE ROLE OF CANDIDA ALBICANS ON THE DEVELOPMENT OF STOMATITIS IN PATIENTS WEARING DENTURES
}

\author{
Jovanović Milica, ${ }^{1}$ Obradović Radmila, ${ }^{2}$ Pejčić Ana, ${ }^{2}$ Stanišić Dragana, ${ }^{1}$ \\ Stošić Nenad, ${ }^{3}$ Popović Žana ${ }^{4}$ \\ ${ }^{1}$ University of Kragujevac, Faculty of Medical Sciences, Department of Dentistry, Serbia \\ ${ }^{2}$ Department of Oral medicine and Periodontology, Clinic of Dentistry, \\ Faculty of Medicine, University of Nis, Serbia \\ ${ }^{3}$ Department of Dental Pathology and Endodontics, Clinic of Dentistry, \\ Faculty of Medicine, University of Nis, Serbia \\ ${ }^{4}$ University of Kragujevac, Faculty of Medical Sciences, student of doctoral studies, Serbia
}

Primljen/Received 22. 06. 2018. god.

\begin{abstract}
Denture stomatitis is the most common inflammatory reaction that occurs in people who wear dentures. It is believed that in $60-65 \%$ of cases the cause of this inflammation is infections by yeasts from the genus Candida $(C$.), primarily Candida albicans infection. C. albicans is a part of the normal microflora of the respiratory and digestive tract. This yeast has the ability to adhere to the oral mucosa and to the base of the denture, as well as to form a biofilm. Its virulence is especially supported by the state of weakened resistance of the organism, when C. albicans expresses its pathological effect. This paper presents the pathogenesis of C. albicans-associated denture stomatitis, as well as the most common diagnostic and therapeutic procedures used to diagnose and successful therapy.
\end{abstract}

Key words: dentures, stomatitis, Candida albicans, biofilm, oral hygiene.

\section{INTRODUCTION}

Denture stomatitis is a very common inflammatory reaction occurring in the carriers of the dentures and involves the mucous membrane underneath the base of the denture $(1,2)$. The etiology of this process is multifactorial, but in $89 \%$ of cases, the occurrence of denture stomatitis is associated with infection of yeast of the genus Candida (C.) (3). Candida species are microorganisms that form part of the normal microflora of the oral cavity. However, if the condition of the normal flora is disturbed or the general resistance of the organism is reduced, Candida species cause inflammation on the surface of mucosa, which is most often ma-
Prihvaćen/Accepted 28. 07. 2018. god.

nifest in the form of denture stomatitis in the denture carriers. For the first time Candida species were described by Cahn in 1936 as possible causes of this inflammatory process (4). Candida albicans is thought to be most responsible for the development of inflammation, although there are studies proving the participation of other yeasts of this strain in the development of oral candidiasis and, therefore, denture stomatitis. Among them there are C. dubliniensis, C. parapsilosis, C. krusei, C. tropicalis and C. glabrata $(5,6)$. Their primary localization is on the dorsal side of the tongue and on the oral mucosa, while the biofilm covering the surface of the teeth colonizes secondary (7). Increased use of antifungal drugs in the treatment of candidiasis has lead to that non-albicans Candida species can also contribute to the development of this infection (8).

Therapy of denture stomatitis involves the maintenance of adequate oral hygiene, removal of dentures during the night, the use of various disinfectants such as sodium hypochlorite and chlorhexidine, as well as the use of local and systemic antifungal drugs $(1,9)$. In addition to antifungal agents, in the treatment of Candida-associated denture stomatitis, extracts of various plants that have antifungal, anti-iflamatory and antioxidant effect are increasingly applied.

\section{PATHOGENESIS OF DENTURE STOMATITIS ASSOCIATED WITH CANDIDA ALBICANS}

C. albicans is a part of the normal microflora of the respiratory and digestive tract. However, in certain 
situations, especially in the case of immunodeficiency, it can exhibit pathological effects and cause candidiasis. Factors that contribute to its pathological effect are the ability of this yeast to adhere to mucosal cells, to convert from single cell to filamentous form, to secret enzymes such as aspartyl proteinase and phospholipase, as well as to build biofilm (10).

The role of $C$. albicans in the development of denture stomatitis is associated with the fact that this yeast has the ability to colonize the oral mucosa and the surface of the dentures and build aggregates with oral bacteria (11). What also increases the incidence of denture stomatitis associated with Candida is the fact that the presence of denture reduces the flow of saliva and oxygen to the tissues below the denture base, which increases the local acidity and anaerobic conditions and thus contributing to the growth of yeasts (12).

On the other hand, $C$. albicans has the affinity to adhere to the acrylic from which denture is made, and the acrylic resin possesses certain characteristics, such as hydrophobicity, which accelerates adhesion as a major step associated with the formation of biofilm $(12,13)$.

Formation of $C$. albicans biofilm goes through three phases. In the first phase, which lasts 1-11 hours, the $C$. albicans cells adhere to the rough surface of the denture, due to the action of hydrophobic and electrostatic forces between the cells and the surface of the denture. In a second phase that lasts 12-30 hours, the biofilm consists of a non-cellular layer or a so-called extracellular polymer substance that covers microcolonies of yeasts, while the third phase is the maturation phase of biofilm occurring within the 38-72 hours $(9,14)$.

Factors that favoring the adherence and formation of biofilm are the roughness of the inner surface of the dentures, the influence of salivary pelicla, as well as hydrophobic and electrostatic interactions (9).

The rough surface of the acrylate promotes increased retention of microorganisms and protects them from the forces that tend to remove, leaving the microorganisms trapped by the irregular surface of the prosthesis, even after cleansing (15). Also, the traumatic factors such as mechanical trauma caused by loose prosthesis can increase the risk of tissue penetration and colonization of Candida species (16). The age of the prosthesis is also an important factor, because it is more difficult to maintain hygiene if prosthesis are worn for a long time and there is a tendency towards to porosity of denture base, which favors the occurrence of infection (17).

As for the effect of saliva on C. albicans adhesion on the prosthesis surface, this effect is still controversial $(7,16,18)$. Saliva plays an important role in mechanical cleansing and contains certain innate immune molecules such as lysosomes, lactoferrin, calprotectin, and IgA immunoglobulin, which reduce adhesion of $C$. albicans for oral surfaces $(2,19)$. Increased saliva flow allows the elimination of carbohydrates that are metabolized by bacteria that produce acidic products, and also the buffer saliva system neutralizes these acidic products, as well as the acids introduced through food and drink (20).

On the other hand, saliva proteins such as mucin and staterine act as adhesion receptors for manoproteins present in Candida species (12). Reduction or complete absence of saliva in individuals with xerostomia causes a disbalance in the normal microbiological composition, favoring the proliferation of Staphylococcus aureus which inhibits the adaptation of the commensal (21).

A particularly important factor that promotes the adhesion and proliferation of C. albicans for oral mucosa and therefore the base plate of the dentures is a low $\mathrm{pH}$ in the oral cavity. It is believed that $\mathrm{pH} 3$ is critical, because it provides enzymatic activity of proteinases and phospholipases, which are the main factors of Candida virulence, due to their cytotoxic and cytolytic effects $(12,16)$. It is also observed that the $\mathrm{pH}$ value of oral mucosa in the elderly and edentulous patients are significantly lower than in younger and in patients with teeth, because the function of the salivary glands is reduced in the elderly, and this is in favor of the development of denture stomatitis in these patients because they are the most frequent carriers of dental prostheses $(22,23)$.

Hydrophobicity and electrostatic interactions influence the development of denture stomatitis caused by $C$. albicans by the fact that hydrophobic surfaces reduce cell adhesion, while yeasts whose surface has a positive charge are more adherent unlike the repulsive forces which exist between the negatively charged yeast and polymer surfaces (16).

In addition to numerous local factors responsible for the adhesion and colonization of $C$. albicans for oral mucosa and the base of the denture, there are also certain systemic factors that can accelerate the development of this infection. Particularly important is the state of immunodeficiency, in which Candida becomes more virulent and leads to the formation of oral candidiasis, including one or more places in the oral cavity (7). The most significant immunodeficiency are HIV infection, hereditary deficiency of myeloperoxidase and some syndromes, such as DiGeorge's syndrome (12).

Some of systemic factors that can increase a risk of denture stomatitis are diabetes mellitus, long-term use of antibiotics and corticosteroids, as well as kidney diseases $(16,24)$.

Particularly diabetes mellitus is associated with the onset of oral candidiasis, and consequently in pati- 
ents who wear dental prostheses is associated with denture stomatitis (25).

Some studies find that it is not important only the presence of disease how much is important to control glycemic in diabetes, because poorly controlled glycemic will reduce salivary flow and $\mathrm{pH}$ in the oral cavity, increasing salivary glucose levels (24). Moreover, besides the presence of a high concentration of salivary glucose combined, low salivary secretion may enhance growth of yeasts and their adherence in epithelial oral cells (26).

Different kidney diseases requiring repeated and prolonged antibiotic therapy and sulphonamide therapy indirectly lead to the occurrence of oral candidiasis and denture stomatitis because these drugs change normal microflora and promote the growth of yeasts (16).

\section{DIAGNOSIS AND TREATMENT OF DENTURE STOMATITIS ASSOCIATED WITH CANDIDA ALBICANS}

Denture stomatitis is usually the asymptomatic inflammatory process and in this case it is usually revealed on routine dental examinations in the form of erythema or edema of the mucosa that is in contact with the prosthesis. Symptoms that the patients may complain are halitosis, slight bleeding, and swelling in inflamed area, or burning sensation, xerostomia or any alterations of taste (27). Denture stomatitis can be also associated with some other oral diseases such as medial rhomboid glossitis, atrophic glossitis and angular cheilitis, and these states have been recognized as Candida-associated lesions (28).

In general, to establish the diagnosis of oral candidiasis, there are several methods that can be used, such as taking a swab, target tissue biopsy (eg. palate), examining a saliva sample, so which method will be used depends on the nature of the lesion being examined (12). Seeding of samples on the nutrients the presence of yeasts is demonstrated. By increasing the colonies of yeasts on different nutrient media, a diagnosis of the species within the genus Candida $(C$.) can be given, however, the detection of hifa (an important factor for invasiveness, adhesion and virulence) by microscopy is for now a "golden" standard for the exact diagnosis of Candida-associated denture stomatitis (29).

Altough the culture-based identification is the gold standard for the diagnosis of fungal infection, detection and identification of fungal DNA by PCR is one of the most powerful and popular tools for the early detection and identification of pathogenic fungi, including Candida species (30). The PCR is the most sensitive of the existing rapid methods to detect microbial pathogens in clinical specimens. The PCR include several critical steps such as, DNA extraction, PCR amplification and the detection of amplicons (31). On the other hand, conventional PCR has a big impact with very good results in fungal identification, but researchers have difficulties due to the post-PCR steps for amplicon evaluation such as agarose gel electrophoresis (32). Due to it is suggested to use real-time PCR or real-time quantitative PCR (qPCR) assays, because of these methodes allows the researchers to actually view the increase in the amount of DNA as it is amplified and post-PCR manipulation of the amplicon is not required $(32,33)$.

Although Candida-associated denture stomatitis is often asymptomatic, this inflammatory process should be treated properly, because it can act as a reservoir for the development of severe inflammation which consequently leads to bone resorption (12). Therapy approach is complex due to multifactorial etiology, but some basic postulates in the therapy of these changes involve the use of local and systemic antifungal drugs, the use of disinfectants, the maintenance of adequate oral hygiene and hygiene of the prosthesis $(7,9,16)$.

The use of antifungal drugs depends on the oral symptoms and the history of the patient's disease. In the case of an uncomplicated inflammatory process, the use of local antifungal drugs, available in the form of gel, lozenge, cream and oral suspensions is recommended (2).

The most commonly drugs used locally are nystatin and amphotericin b, while fluconazole oral suspension is proving to be a very effective drug in the treatment of oral candidiasis. Another topic drugs widely used are miconazole and clotrimazole (34). Mostly all drugs lead to the cessation of symptoms after administration of 12 to 14 days.

Nystatin is the most commonly used drug in oral candidiasis therapy, which is administered four times a day for two weeks in the form of oral pastille and suspension. The oral rinse contains sucrose, so it is is useful in edentulous patients and those with oral dryness such as patients receiving radiotherapy and those with HIV infection (26). In some studies, nystatin has been shown to be ineffective for Candida lesions in cancer patients (35). In addition, nystatin, myconazole cream $(2 \%)$ and clotrimazole cream (1\%) are also used in the treatment of denture stomatitis associated with angular cheilitis (23). Fluconazole oral suspension is administered in a dosage of $10 \mathrm{mg} / \mathrm{ml}$ aqueous suspension by administering $5 \mathrm{ml}$ daily for 7 or 14 days (34).

There have been several studies comparing topical and systemic drugs. Isham $\mathrm{N}$ et al. compared the use of ketoconazole tablets (200 mg daily) with topical ketoconazole ( $2 \%$ twice daily) and miconazole muco- 
adhesive tablets in the treatment of denture stomatitis (36). Due to the adverse effects of ketoconazole like nausea, vomiting and gastrointestinal problems it has been suggested the use of other drugs when treating candidiasis associated with wearing of dentures (37, 38). Thus the use of miconazole mucoadhesive tablet was established as the drug of first line of defense for this type of candidiasis (34).

The use of systemic antifungal drugs is recommended for severe forms of Candida-associated denture stomatitis, when local therapy has not been effective, as well as in immunodeficiency patients. Among systemic antifungal drugs, fluconazole is particularly useful due to low toxicity and good tolerability. The appropriate dose is between $50-100 \mathrm{mg}$ daily $(26,34)$. On the other hand itraconazole is applied in case of resistance to fluconazole. Ketoconazole is also effective as fluconazole, but its use is not recommended in the elderly due to interactions with macrolide antibiotics and antihistamines, and because of adverse effects such as hepatotoxicity (26). Amphotericin B has previously been administered intravenously in the treatment of Candida-associated denture stomatitis, but today its application was reduced due to nephrotoxicity (39).

Antifungal drugs of new generations used in the treatment of oral candidiasis and severe forms of denture stomatitis associated with Candida are posaconazole, ravuconazole and echinocandin such as caspofungin, micafungin and anidulafungin. They represent less toxic alternatives than amphotericin B (26).

The aim of the disinfectants used in denture stomatitis is to reduce the formation of biofilm on the prostheses and inhibit the growth of yeasts (12). Especially applied disinfectants are chlorhexidine gluconate and sodium hypochlorite (16). Chlorhexidine gluconate is effective against numerous bacteria, viruses, bacterial spores and against yeasts (12). It can be applied as a $0.2 \%$ solution for rinsing the oral cavity, however, much better results are obtained when it is used in the form of a $2 \%$ solution for immersing of the prosthesis. However, it is good to have in mind that chlorhexidine reduces the effectiveness of nystatin when it is administered at the same time, so the advice is to use nystatin at least $30 \mathrm{mi}-$ nutes after rinsing the mouth with chlorhexidine (40). Another very effective disinfectant that reduces the formation of $C$. albicans biofilms is sodium hypochlorite, which is used in the form of a $0.2 \%$ solution, and it is also advised to immerse the dentures into this solution. However, the use of sodium hypochlorite must be restricted to a shorter period of time because it has the ability to damage the dentures $(12,16)$.

All therapeutic methods in the treatment of denture stomatitis would not produce results without adequate oral hygiene. Maintenance of adequate oral hygiene and local application of antifungal drugs in most cases are sufficient for the treatment of uncomplicated oral candidiasis. Oral hygiene includes daily cleaning of teeth, tongue and dental prostheses. Dentures should be removed at night or at least six hours during the day (26).

\section{ALTERNATIVE AGENTS IN THE TREATMENT OF DENTURE STOMATITIS ASSOCIATED WITH CANDIDA ALBICANS}

In addition to the classic therapy of denture stomatitis associated with C. albicans, lately it is increasingly resorting to alternative agents that have less side effects and at the same time exhibit antibacterial and anti-inflammatory activity. There are a large number of preparations based on plants and their essential oils that have an anti-inflammatory effect and as natural antiseptics express antifungal and antibacterial activity (9). Natural compounds from essential oils: eugenol, farnesol, geraniol, linalool, menthol, menthone, terpinen- 4-ol, $\alpha$-terpineol and tyrosol, carvacrol, expressed strong antifungal in vitro activity (12).

One of the investigated essential oils exhibiting a remarkable antioxidative and antifungal activity is the thyme oil. Thyme oil is very rich in phenols and is classified as antifungicide due to its strong effect on Candi$d a$ species (41).

Some authors, have shown that timolol as a component of thyme oil possessed pretty strong antifungal activity against $C$. albicans in vitro. In view of its broad activity, thyme essential oil may be used as a natural disinfectant for the prevention of denture stomatitis (42). Omran SM et al. in their study have examined the effect of essential oils on Candida yeasts, they found that thyme oil had the highest inhibitory effect (43).

The essential oil of tea tree has a significant effect on C. albicans. Pachava et al. have shown that tea tree oil incorporation to denture soft liner decreased C. albicans growth significantly (44). Similarly, Amornvit et al. combined lemongrass essential oil to tissue conditioner and demonstrated the anti-Candida activity (45).

On forty isolates of $C$. albicans from the oral cavity obtained from twenty-five patients using orthodontic appliance, eight essential oils were applied, the largest antifungal effect was shown by the essential oil of cinnamon, laurel, lemon and mint (46).

It is also considered that garlic in combination with nystatin may be highly effective in the treatment of oral candidiasis, in particular those associated with denture stomatitis $(9,47)$. Other essential oils that that have a positive antifungal effect are the oil of the following plants: Pelargonium graveolens, Satureja hortensis, Zataria multiflora, Punica granatum, Salvia of- 
ficinalis, Streblus asper, Boesenbergia pandurate, Phyllanthus emblica, Scutellaria baicalensis, Azadirachta indica, Melaleuca alternifolia $(9,48)$.

\section{CONCLUSION}

Denture stomatitis is one of the most common inflammatory reactions affecting carriers of dental prostheses, and in most cases it is associated with infection of yeast of the genus Candida, primarily with C. albicans. Although this is the most common asymptomatic tissue reaction below the prosthesis base, it is important to diagnose the disease as early as possible, otherwise Candida would act as a reservoir for more exten- sive infections that would eventually lead to bone resorption. Treatment of Candida-associated denture stomatitis requires the use of antifungal drugs and adequate oral hygiene.

\section{DECLARATION OF INTEREST}

The autors declare that there are no conflicts of interests.

\section{Licensing}

This work is licensed under a Creative Commons Attribution 4.0 International (CC BY 4.0) License.

\title{
Sažetak
}

\section{ULOGA CANDIDE ALBICANS U RAZVOJU STOMATITISA KOD PACIJENATA KOJI NOSE ZUBNE PROTEZE}

\author{
Jovanović Milica, ${ }^{1}$ Obradović Radmila, ${ }^{2}$ Pejčić Ana, ${ }^{2}$ Stanišić Dragana, ${ }^{1}$ \\ Stošić Nenad, ${ }^{3}$ Popović Žana ${ }^{4}$ \\ ${ }^{1}$ Univerzitet u Kragujevcu, Fakultet medicinskih nauka, Katedra za stomatologiju, Srbija \\ ${ }^{2}$ Odeljenje za oralnu medicinu i parodontologiju, Klinika za stomatologiju, Medicinski fakultet, Univerzitet u Nišu, Srbija \\ ${ }^{3}$ Odeljenje za bolesti zuba i endodonciju, Klinika za stomatologiju, Medicinski fakultet, Univerzitet u Nišu, Srbija \\ ${ }^{4}$ Univerzitet u Kragujevcu, Fakultet medicinskih nauka, student doktorskih studija, Srbija
}

Protezni stomatitis je najčešća zapaljenska reakcija koja se javlja kod osoba koje nose zubne proteze i obično zahvata palatinalnu sluzokožu. Smatra se da je u $60-65 \%$ slučajeva uzrok ovog zapaljenja infekcija gljivicama iz roda Candida (C.), a prevashodno Candida albicans. Ova gljivica ima sposobnost da adherira za oralnu sluzokožu i za bazu protezne ploče, i da for- mira biofilm. Njena virulencija je naročito potpomognuta stanjima oslabljene otpornosti organizma, $\operatorname{kada} C$. albicans ispoljava svoje patološko dejstvo. U ovom radu prikazana je patogeneza proteznog stomatitisa udruženog sa C. albicans, kao i najčešće dijagnostičke i terapijske procedure koje se koriste za postavljanje dijagnoze i sprovođenje uspešne terapije.

\section{REFERENCES}

1. Gendreau L, Loewy ZG. Epidemiology and etiology of denture stomatitis. J Prosthodont. 2011; 20(4): 251-60.

2. Sharma D, Sharma N. Denture stomatitis - a review. IJOCR. 2015; 3(7): 81-5.

3. Gauch LM, Pedrosa SS, Silveira-Gomez F, Esteves RA, Mrques-da-Silva SH. Isolation of Candida spp. from denture-related stomatitis in Pará, Brazil. Braz J Microbiol. 2018; 49(1): 148-151.

4. Ramage G, Tomsett K, Wickes BL, Lo'pez-Ribot JL, Redding SW. Denture stomatitis: A role for Candida biofilms. Oral Surg Oral Med Oral Pathol Oral Radiol Endod. 2004; 98(1): 53-9.

5. Tay LY, Herrera DR, Gomes BP, dos Santos FA, Jorge JH. Identification of Candida Spp. in patients with denture stomatitis: relationship with gender, age, time of denture use and Newton's classification. J Dent App. 2014; 1(3): 46-50.

6. Zomorodian K, Haghighi NN, Rajaee N, Pakshir K, Tarazooie B, Vojdani M, et al. Assessment of Candida species colonization and denture-related stomatitis in complete denture wearers. Med Mycol. 2011; 49(2): 208-11.
7. Hoshing C, Dixit S, Mootha A, Diwan N. Role of Candida albicans in denture stomatitis. J Indian Acad Oral Med Radiol. 2011; 23(4): 617-19.

8. Martinez M, Lopez-Ripot JL, Kirkpatrick WR, Coco BJ, Bachmann SP, Patterson TF. Replacement of Candida albicans with C. dubliniensis in human immunodeficiency virus infected patients with oropharyngeal candidiasis treated with fluconazole. J Clin Microbiol. 2002; 40(9): 3135-9.

9. Petrović M, Kostić M, Kostić M, Krunić N, Igić M, Pešic $\mathrm{Z}$ et al. Therapeutic alternatives of natural compounds in treatment of candida-associated denture stomatitis. Acta Medica Medianae. 2014; 53(1): 73-9.

10. Soll DR. Candida commensalism and virulence: the evolution of phenotypic plasticity. Acta Trop. 2002; 81(2): 101-10.

11. O'Donnell LE, Robertson D, Nile CJ, Cross Lj, Riggio $\mathrm{M}$, Sherriff A et al. The oral microbiome of denture wearers is influenced by levels of natural dentition. PloS One. 2014: 10(9): e0137717.

12. Gleiznys A, Zdanavičien $\square$ E, Žilinskas J. Candida albicans importance to denture wearers. A literature review. Stomatologija Baltic Dental and Maxillofacial Journal. 2015; 17(2): 54-66. 
13. Lazarin AA, Zamperini CA, Vergani CE, Wady AF, Giampaolo ET, Machado AL. Candida albicans adherence to an acrylic resin modified by experimental photopolymerised coatings: an in vitro study. Gerodontology. 2014; 31(1): 25-33.

14. Agarwal V, Lal P, Pruthi V. Prevention of Candida albicans biofilm by plant oils. Mycopathologia. 2008; 165(1): 13-9.

15. Zamperini CA, Machado AL, Vergani CE, Pavarina AC, Giampaolo ET, da Cruz NC. Adherence in vitro of Candida albicans to plasma treated acrylic resin. Effect of plasma parameters, surfaceroughness and salivary pellicle. Arch Oral Biol. 2010; 55(10): 763-70.

16. Salerno C, Pascale M, Contaldo M, Esposito V, Busciolano M, Milillo L et al. Candida-associated denture stomatitis. Med Oral Patol Oral Cir Bucal. 2011; 16(2): e139-43.

17. Shamimul HK. Denture stomatitis: a literature review. JOHS 2015; 6(2): 65-9.

18. Kanaguchi N, Narisawa N, Ito T, Kinoshita Y, Kusumoto $\mathrm{Y}$, Shinozuka $\mathrm{O}$ et al. Effects of salivary protein flow and indigenous microorganisms on initial colonization of Candida albicans in an in vivo model. BMC Oral Health. 2012; 12:36. doi: 10.1186/1472-6831-12-36.

19. Dangi YS, Soni ML, Namdeo KP. Oral candidiasis: a review. Int J Pharm Pharm Sci. 2010; 2(4): 36-41.

20. Dandekeri S, Prasad K, Shetty M, Hegde C, Sowmya MK, Jagadeesh M. Occurrence of streptococcus and Candida species and salivary ph in patients wearing complete denture. Int J Health Rehabil Sci. 2013; 2(4): 198-203.

21. Baena-Monroy T, Moreno-Maldonado V, Franco-Martínez F, Aldape-Barrios B, Quindos G, Sanchez-Vargas LO. Candida albicans, Staphylococcus aureus and Streptococcus mutans colonization in patients wearing dental prosthesis. Med Oral Patol Oral Cir Bucal. 2005; 10(1): 27-39.

22. Chopde N, Jawale B, Pharande A, Chaudhari L, Hiremathn V, Redasani R. Microbial colonization and their relation with potential cofactors in patients with denture stomatitis. J Contemp Dent Pract. 2012; 13(4): 456-9.

23. Abraham CM. Advances and emerging techniques in the identification, diagnosis and treatment of oral candidiasis. Open Path J. 2011; 5: 8-12.

24. Farah CS, Lynch N, McCullough MJ. Oral fungal infections: an update for the general practitioner. Aust Dent J. 2010; 55(Suppl 1): 48-54.

25. Motta-Silva AC1, Aleva NA, Chavasco JK, Armond MC, França JP, Pereira Lj. Erythematous oral candidiasis in patients with controlled type II diabetes mellitus and complete dentures. Mycopathologia. 2010; 169(3): 215-23.

26. Obradović RR, Kesić LjG, Petrović MS, Stanković IV. Diferencijalno-dijagnostičke i terapijske karakteristike oralne kandidijaze. Acta Stom Naissi. 2013; 29(68): 1315-23.

27. Mago J, Mittal K, Kaur M, Kaur A, Kaunda M. Denture stomatitis - a case report and an update. World J Pharm Med Res. 2016; 2(4): 224-6.

28. Nakamura S, Okamoto MR, Yamamoto K, Tsurumoto A, Yoshino Y, Iwabuchi $\mathrm{H}$ et al. The Candida species that are important for the development of atrophic glossitis in xerostomia patients. BMC Oral Health. 2017; 17(1): 153.

29. Webb BC, Thomas CJ, Willcox MD, Harty DW, Knox KW. Candida - associated denture stomatitis. Aetiology and management: a review. Part I. Factors influencing distribution of Candida species in the oral cavity. Aust Dent J. 1998; 43(1): 45-50.
30. Harmal NS, Khodavandi A, Alshawsh MA, Jamal F, Sekawi Z, Peng NK, et al. Identification and differentiation of Candida species using specific polymerase chain reaction (PCR) amplification of the phospholipase B gene. Afr J Microbiol Res. 2013; 7(20): 2159-66.

31. Abaci Ö, Halki-Uztan A, Ates M. Specific identification of Candida albicans and Candida dubliniensis by PCR using species-specific primers. Ann Microbiol. 2008; 58(2): 325-31.

32. El-Naggar MY, Al-Basri HM, Karam El-Din AZ.. Molecular diagnosis of Candida albicans using real-time polymerase chain reaction of a CaYST1 gene. JTUSCI. 2010; 3(1): 8-13.

33. Zhang J, Hung GC, Nagamine K, Li B, Tsai S, Lo SC. Development of Candida-specific real-time PCR Assays for the detection and identification of eight medically important Candida Species. Microbiol Insights. 2016; 9: 21-8.

34. Garcia-Cuesta C, Sarrion-Pérez MG, Bagán JV. Current treatment of oral candidiasis: A literature review. J Clin Exp Dent. 2014; 6(5): e576-82.

35. Tarçın BG. Oral Candidosis: Aetiology, Clinical Manifestations, Diagnosis and Management. MÜSBED. 2011; 1(2): $140-8$.

36. Isham N, Ghannoum MA. Antifungal activity of miconazole against recent Candida strains. Mycoses. 2010; 53(5): 434-7.

37. Khozeimeh F, Shahtalebi MA, Noori M, Savabi O. Comparative evaluation of ketoconazole tablet and topical ketoconazole $2 \%$ in orabase in treatment of Candida-infected denture stomatitis. J Contemp Dent Pract. 2010; 11(2): 17-24.

38. Brito GN, InocLncio AC, Querido SM, Jorge AO, Koga-Ito CY. In vitro antifungal susceptibility of Candida spp. oral isolates from HIV-positive patients and control individuals. Braz Oral Res. 2011; 25(1): 28-33.

39. Vasconcellos AAD, Vasconcellos AAD, Chagas RB, Gonçalve LM. Candida-associated denture stomatitis: Clinical relevant aspects. Clin Microbial. 2014; 3:4.

40. DWilliams DW, Kuriyama T, Silva S, Malic S, Lewis MA. Candida biofilms and oral candidosis: treatment and prevention. Periodontology 2000. 2011; 55(1): 250-65.

41. Palmeira-de-Oliveira A, Slgueiro L, Palmeira-de-Oliveira R, Martinez-de-Oliveira J, Pina- Vaz C, Queiroz JA et al. Anti -Candida Activity of Essential Oils. Mini-Reviews in Medicinal Chemistry. 2009; 9(11): 1292-305.

42. Liu X, Zheng X, Fang W, Zhang Y. Screening of food additives and plant extracts against Candida Albicans in vitro for prevention of denture stomatitis. Procedia Environmental Sciences. 2012; 12: 1361-6.

43. Omran SM, Esmaeilzadeh S, Rahmani Z. Laboratory study of anticandidal activity of thyme, pennyroyal and lemon essential oils by micro dilution method. Jundishapur J Microbiol. 2010; 3(4): 161-7.

44. Pachava KR, Nadendla LK, Allurib LSC, Tahseen H, Sajja NP. In vitro antifungal evaluation of denture soft liner incorporated with tea tree oil: a new therapeutic approach towards denture stomatitis. J Clin Diagn Res. 2015; 9(6): 62-4.

45. Amornvit P, Choonharuangdej S, Srithavaj T. Lemongrass-incorporated tissue conditioner against Candida albicans culture. J Clin Diagn Res. 2014; 8(7): ZC50-2.

46. Carvalhinho S, Costa AM, Coelho AC, Martins E, Sampaio A. Susceptibilities of Candida albicans mouth isolates to antifungal agents, essential oils and mouth rinses. Mycopathologia. 2012; 174(1): 69-76. 
47. Bakhshi M, Taheri JB, Shabestari SB, Tanik A, Pahlevan R. Comparison of therapeutic effect of aqueous extract of garlic and nystatin mouthwash in denture stomatitis. Gerodontology. 2012; 29(2): e680-4.
48. Marcos-Arias C, Eraso E, Madariaga L, Quindos G. In vitro activities of natural products against oral Candida isolates from denture wearers. BMC Complement Altern Med. 2011; 11:119.

\section{Correspondence to / Autor za korespondenciju}

Radmila Obradović, DDS, PhD, Assistant Professor

Department of Oral medicine and Periodontology

Faculty of Medicine, University of Nis

Address: 18000 Nis, Serbia, 81, Dr. Zoran Djindjic Blvd

Fax: +381184238770

E-mail address:dr.rada@yahoo.com 